University of Nebraska - Lincoln

DigitalCommons@University of Nebraska - Lincoln

Faculty Publications, UNL Libraries

Libraries at University of Nebraska-Lincoln

$1-26-2009$

\title{
The World of Charles J. Kappler: A Digital Portrait
}

Charles D. Bernholz

University of Nebraska-Lincoln, cbernholz2@unl.edu

Robert J. Weiner

Syracuse University College of Law, rjweiner@law.syr.edu

Follow this and additional works at: https://digitalcommons.unl.edu/libraryscience

Part of the Indian and Aboriginal Law Commons, and the Library and Information Science Commons

Bernholz, Charles D. and Weiner, Robert J., "The World of Charles J. Kappler: A Digital Portrait" (2009). Faculty Publications, UNL Libraries. 181.

https://digitalcommons.unl.edu/libraryscience/181

This Article is brought to you for free and open access by the Libraries at University of Nebraska-Lincoln at DigitalCommons@University of Nebraska - Lincoln. It has been accepted for inclusion in Faculty Publications, UNL Libraries by an authorized administrator of DigitalCommons@University of Nebraska - Lincoln. 


\title{
The World of Charles J. Kappler: A Digital Portrait
}

\author{
Charles D. Bernholz \\ Robert J. Weiner, Jr.
}

\begin{abstract}
Charles J. Kappler (1868-1946) is known almost exclusively for his Indian Affairs: Laws and Treaties compilation, yet his life and his career were much fuller. Besides serving as Clerk for the Senate Committee on Indian Affairs, he was co-counsel for the Pious Fund of the Californias v. Mexico proceedings before the Permanent Court of Arbitration in The Hague and, in one role or another, played a substantial part in many significant federal Indian law cases before the United States Supreme Court in the years leading up to the establishment of the Indian Claims Commission. A digital Web site has been developed to present lesser known aspects of his personal and professional life.
\end{abstract}

KEYWORDS. Charles J. Kappler, American Indians, treaties

\section{THE MAN}

The final treaty recognized by the United States Department of State, between American Indians and the federal government, is ratified treaty number 374, the Treaty with the Nez Perces, $1868 .{ }^{1}$ Charles J. Kappler (Fig. 1) was born on November 16 of that year-just 95 days after this transaction-to German immigrants Anton and Suzanna, a shoemaker and housewife living in Washington, DC. ${ }^{2}$ With two brothers and two sisters

Charles D. Bernholz is Government Documents Librarian, Love Memorial Library, University of Nebraska, Lincoln, NE 68588 (E-mail: cbernholz2@ unl.edu).

Robert J. Weiner, Jr. is Electronic Services Librarian, H. Douglas Barclay Law Library, Syracuse University College of Law, Syracuse, NY 13244 (E-mail: rjweiner@law.syr.edu).

Legal Reference Services Quarterly, Vol. 27(4) 2008

(C) 2008 by The Haworth Press. All rights reserved.

doi: 10.1080/02703190802701099 
to round out the family, ${ }^{3}$ Kappler "graduated from public and parochial schools of the District"4 and then studied stenography and typing with Theodore F. Shuey, considered at that time to be the dean of Congressional reporters. ${ }^{5}$ Later, an LL.B. degree in 1896 and an LL.M. the following year were attained from the Law School at Georgetown University. Admission to the Bar occurred in 1896 and records indicate his admittance to the United States Supreme Court. ${ }^{6}$

During the 57th and 58th Congresses between the years 1901 and 1905, Kappler served as Clerk to the Senate Committee on Indian Affairs ${ }^{7}$ and became more involved with federal Indian law. Part of the accomplishments of this committee was legislation to bring together for congressional use the final texts of all recognized treaties created between American Indians and the federal government. ${ }^{8}$ Treaty-making with the tribes had terminated

FIGURE 1. Charles J. Kappler, 1868-1946. (Star Collection, DC Public Library; (C) Washington Post) Reprinted with permission.

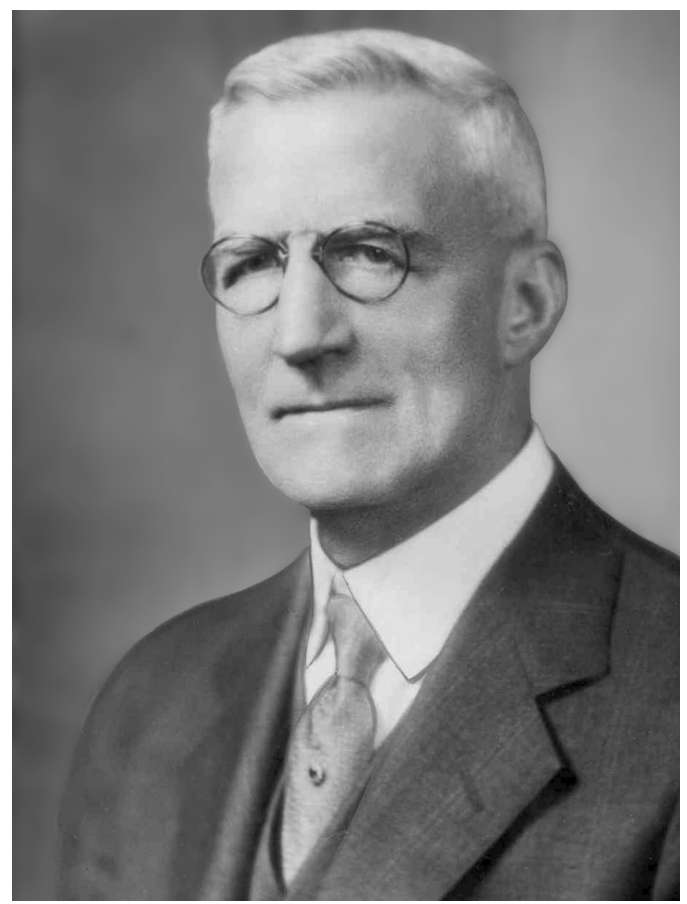


in 1871 (16 Stat. 544, 566), but these documents, as the law of the land, were scattered throughout 10 volumes of the Statutes at Large.

Kappler's Indian Affairs: Laws and Treaties, familiar to all law librarians, was the ultimate product of this mandate. ${ }^{9}$ Five volumes emerged between 1903 and 1941, with the first two from 1903 expanded and reissued the following year. ${ }^{10}$ The remaining three tomes were developed after Kappler left federal employment in $1905^{11}$ and opened a legal office. All but nine of the treaties acknowledged by the Department of State were collected in volume 2 of this set, providing a convenient source for these materials. ${ }^{12}$ In the 1970 s, the second volume was reproduced alone, ${ }^{13}$ and the entire ensemble was republished by a commercial vendor as well as by the federal government. ${ }^{14}$ Finally, the Oklahoma State University Library created a digital portal for these documents. ${ }^{15}$

In the legal sphere, Kappler's skills as an attorney are revealed by a portfolio of 91 cases from 1904 through 1945. Among these were state appearances as well as presentations before the federal Court of Claims and Courts of Appeal, and the United States Supreme Court. Twentyeight of these actions concerned federal Indian law, but there were other interesting legal challenges as well.

\section{THE WEB SITE}

These life and career experiences have been brought together in a World Wide Web portrait at http://kappler.unl.edu, under the title Charles J. Kappler-A Life Beyond Indian Affairs: Laws and Treaties. ${ }^{16}$ Within this description is a broader account of his marriages and family life; of his service for the Senate's Irrigation and Reclamation of Arid Lands Committee and its Committee on Indian Affairs; of his performance in 1902 as co-counsel at the first case before the Permanent Court of Arbitration in The Hague, Pious Fund of the Californias v. Mexico $;{ }^{17}$ of his legal career and his representations of various tribes before diverse jurisdictions; and of his adoption by the Crow in 1931 for his assistance to that tribe. It was a rewarding passage and typified the spirit of hard-working immigrant families in America.

His efforts before the courts are summarized in two tables, with expanded remarks for six special situations. The first list enumerates his 91 cases, and reference is made to those specific suits that have been cited in five frequently used handbooks of federal Indian law: Felix S. Cohen's Handbook of Federal Indian Law; the Department of the Interior's Federal 
Indian Law; the second edition of Cohen; the American Indian Law Deskbook; and the third version of Cohen's work. ${ }^{18}$ Shoshone Tribe of Indians v. United States (299 U.S. 476 [1937]) and United States v. Shoshone Tribe of Indians (304 U.S. 111 [1938]) were two Supreme Court actions noted by all five of these sources.

The second table links 38 recognized Indian treaties, referenced by Kappler himself in 28 of his presentations, with the appropriate case citation(s). For example, he employed ratified treaty number 43, the Treaty with the Sauk and Foxes, $1804^{19}$ as well as ratified treaty number 359, the Treaty with the Sauk and Foxes, $1867^{20}$ in both Sac and Fox Indians of Iowa v. Sac and Fox Indians of Oklahoma (45 Ct.Cl. 287 [1910]) and Sac and Fox Indians of the Mississippi in Iowa v. Sac and Fox Indians of the Mississippi in Oklahoma (220 U.S. 481 [1911]). Taken all together, such Indian law representations served as important examples during the long debate that preceded the 1946 creation of the Indian Claims Commission (60 Stat. 1049), empowered to address for the last time any outstanding tribal claims against the federal government. Indeed, this legacy ultimately continued for more than half a century, ending only when the final Indian Claims Commission case-filed in August 1951-was brought to a close by a congressional settlement act in 2006 (120 Stat. 1218).

\section{CONCLUSIONS}

In 1928, the Senate Committee on Printing provided comments on, and its recommendation for, the printing of Kappler's fourth volume. In that report, ${ }^{21}$ the chairman of the committee included correspondence between the Secretary of the Interior and an earlier chairman of the Senate Committee on Indian Affairs. The secretary had remarked that "[t]he compilation of Indian laws and treaties is constantly used and referred to in this department and the office of Indian Affairs, as well as at the several Indian agencies, where the Statutes at Large are not always available. It has been a most useful and convenient document. ..."22 In a companion note, the chairman of the House Committee on Indian Affairs declared, "I have found this work very valuable and know that a similar attitude is held by many others." 23 These favorable considerations were indicative of remarks made during the printing history of the Indian Affairs volumes.

Kappler's enduring influence on the publication of such fundamental Indian law documents, well after his departure in 1905 from federal service, speaks much to the position and relevance of these materials in state and Congressional activities and to their consistent deployment at almost 
every judicial level. This focus on the treaties was associated with his own considerable legal efforts for the tribes and, with the exercise of his personal knowledge of these instruments, most certainly shaped in part by these successful compilation labors. Indeed, subsequent federal legislation led to the creation of an additional pair of volumes, as an update to laws through the beginning of $1971 .^{24}$

The contents of Indian Affairs: Laws and Treaties are still referenced today, as demonstrated in two recent cases: Cheyenne-Arapaho Tribes of Oklahoma v. United States (517 F. Supp. 2d 365, 368 [2007]) before the United States District Court for the District of Columbia, and Confederated Salish \& Kootenai Tribes v. Clinch (336 Mont. 302, 339 [2007]) in the Supreme Court of Montana. In a sense, such contemporary use reaffirms the perception that it has been difficult over the last century to separate Kappler from these American Indian treaties, and vice versa. His volumes-in paper, microform, or online-have functioned throughout as reliable conduits to these important texts, whether for use in or out of the courts. It is unfortunate, though, that there is no comprehensive biography of this man, that there is no vehicle to proclaim his many additional contributions and achievements outside the realm of federal Indian law. Perhaps this Web site, by bringing together other aspects of Kappler's robust personal life and career, will contribute toward a better understanding of these parallel successes.

To further expedite access to the texts of American Indian treaties and to other relevant materials, the University of Nebraska-Lincoln's Center for Digital Research in the Humanities has incorporated this Kappler portrait with links to the Oklahoma State University Library's electronic treaty collection (http://digital.library.okstate.edu/kappler/); to the nine documents absent from that gathering (http://earlytreaties.unl.edu/); to the lexicon of the British and of the American transactions recognized by the Department of State (http://treatylexicon.unl.edu); ${ }^{25}$ and to an array of digitized journal articles regarding cases before various jurisdictions that have cited one or more of these instruments. This treaty portal is offered at http://treatiesportal.unl.edu.

\section{ACKNOWLEDGEMENTS}

We thank Laura Weakly and Karin Dalziel of the Center for Digital Research in the Humanities for their editorial and design expertise in the creation of this electronic resource. 


\section{NOTES}

1. Ratified Indian Treaties, 1722-1869 (National Archives and Records Service, 1966); Charles J. Kappler, Indian Affairs. Laws and Treaties, vol. 2, Treaties. Senate, 58th Congress, 2nd session, Senate Document No. 319, pt. 2, 1024-1025 (Government Printing Office, 1904); and http://digital.library. okstate.edu/kappler/Vol2/treaties/nez1024.htm.

2. John W. Leonard, Who's Who in Jurisprudence: A Biographical Dictionary of Contemporary Lawyers and Jurists, 1925, With a Complete Geographical Index, 803 (John W. Leonard Corp., 1925).

3. Department of the Interior, 1880 Census-District of Columbia, series T9, roll 123, 109 (Government Printing Office, 1880).

4. Charles Kappler Dies; Expert and Writer on Indian Affairs, The Evening Star, 21 January 1946, B4.

5. Charles Kappler Is Authority on Indian Laws and Treaties, The Evening Star, 6 July 1941, C8; John W. Heckel, Questions and Answers, 61 Law Library Journal 313-316 (1968).

6. New Lawyers Admitted to Bar, The Washington Post, 13 December 1896, 14; Charles J. Kappler, Entry Term Minutes, 1863-1938, vol. 8, 12 December 1896, Record Group 21, Records of the District Courts of the United States, 234 (National Archives and Records Administration 1896); Charles J. Kappler, Entry 61, Attorney rolls, 1790-1961, 21 October 1901, Record Group 267, Records of the Supreme Court of the United States (National Archives and Records Administration, 1901).

7. A. J. Halford, Official Congressional Directory for the Use of the United States Congress, first edition, corrected to December 5, 1901. Senate, 57th Congress, 1st session, Senate Document No. 4, pt. 2, 195 (Government Printing Office, 1901).

8. Compilation on Indian affairs, 35 Congressional Record 5619 (1902); Compilation on Indian affairs, 35 Congressional Record 5664-5665 (1902); Treaties, laws, etc., relating to Indian affairs, 37 Congressional Record 290 (1903).

9. See Charles Kappler Is Authority on Indian Laws and Treaties for a contemporary assessment.

10. The pairs are Charles J. Kappler, Indian Affairs. Laws and Treaties. Senate, 57th Congress, 1st session, Senate Document No. 452, pts. 1 and 2 (Government Printing Office, 1903), and Indian Affairs. Laws and Treaties. Senate, 58th Congress, 2nd session, Senate Document No. 319, pts. 1 and 2 (Government Printing Office, 1904).

11. Charles J. Kappler, Indian Affairs. Laws and Treaties, vol. 3, Laws. Senate, 62nd Congress, 2nd session, Senate Document No. 719 (Government Printing Office, 1913); Indian Affairs. Laws and Treaties, vol. 4, Laws. Senate, 70th Congress, 1st session, Senate Document No. 53 (Government Printing Office, 1929); and Indian Affairs. Laws and Treaties, vol. 5, Laws. Senate, 76th Congress, 3rd session, Senate Document No. 194 (Government Printing Office, 1941).

12. See Charles D. Bernholz, Brian L. Pytlik Zillig, Laura K. Weakly \& Zacharia A. Bajaber, The last few American Indian treaties-An extension of the Charles J. Kappler Indian Affairs: Laws and Treaties Internet site at the Oklahoma State University, $30 \mathrm{Li}$ brary Collections, Acquisitions, and Technical Services 47-54 (2006) for a discussion of those remaining nine items. The site's URL is http://earlytreaties.unl.edu/. 
13. Charles J. Kappler, Indian Treaties: 1778-1883 (Amereon House, 1972) and Indian Treaties: 1778-1883 (Interland Publishing, 1973).

14. Charles J. Kappler, Indian Affairs: Laws and Treaties (AMS Press, 1972) and Indian Affairs: Laws and Treaties (Government Printing Office, 1975).

15. Charles D. Bernholz \& Suzanne L. Holcombe, The Charles J. Kappler Indian Affairs: Laws and Treaties Internet Site at the Oklahoma State University, 29 Library Collections, Acquisitions, and Technical Services 82-89 (2005).

16. This site has been cataloged; its OCLC accession number is 281739058 .

17. See http://www.pca-cpa.org/upload/files/Pious_Funds_Award.pdf for the 14 October 1902 conclusions of the Tribunal.

18. Felix S. Cohen, Handbook of Federal Indian Law, With Reference Tables and Index (Government Printing Office, 1942); Department of the Interior, Federal Indian Law (Government Printing Office, 1958); Felix S. Cohen's Handbook of Federal Indian Law (Rennard Strickland, ed., 1982 ed., Michie, 1982); American Indian Law Deskbook (Clay Smith, ed., 3rd ed., University Press of Colorado, 2004); and Cohen's Handbook of Federal Indian Law (Nell Jessup Newton, ed., LexisNexis/Matthew Bender, 2005).

19. Charles J. Kappler, Indian Affairs, vol. 2 (1904), 74-77, and http://digital. library.okstate.edu/kappler/Vol2/treaties/sau0074.htm.

20. Id. at 951-956, and http://digital.library.okstate.edu/kappler/Vol2/treaties/ sau0951.htm.

21. Printing of manuscripts relating to Indian affairs. Senate, 70th Congress, 1 st session, Senate Report No. 200 (Government Printing Office, 1928).

22. Id. at 2.

23. Id.

24. Department of the Interior, Kappler's Indian Affairs: Laws and Treaties, vol. 6. Laws: Compiled from February 10, 1939 to January 13, 1971, Part I (Government Printing Office, 1979), and Kappler's Indian Affairs: Laws and Treaties, vol. 7. Laws: Compiled from February 10, 1939 to January 13, 1971, Part II (Government Printing Office, 1979).

25. A sketch of this Web site is contained in Charles D. Bernholz, Brian L. Pytlik Zillig \& Cokie G. Anderson, The Words You Brought Us: Digital Lexicon of the Recognized American Indian Treaties, 32 Library Collections, Acquisitions, and Technical Services 104-106 (2008). 